\title{
ANALISIS PEMILIHAN KARAKTER SUPERHERO SEBAGAI LISENSI PRODUK PADA MINUMAN SUSU FRISIAN FLAG (MILKY, FRUITY, DAN MUT MUT) DALAM MENARIK MINAT BELI KONSUMEN.
}

\author{
Aji Kresno Murti ${ }^{1}$, Muhammad Sani Kurniawan ${ }^{2}$ \\ E mail: ajikresnomurti@ yahoo.com ${ }^{1}$ \\ E mail: sani_app@yahoo.com ${ }^{2}$
}

Program Studi Manajemen Pemasaran Industri Elektronika Politeknik APP Jakarta Program Studi Perdagangan Internasional Wilayah ASEAN dan RRT Politeknik APP Jakarta

Received: July 20, 2017; Accepted: October 31, 2017; Published: November 30, 2017

\begin{abstract}
This research is an analysis that aimed to see the suitability between super hero character (Iron Man, Spiderman, Thor, Captain America) chosen by Frisian Flag Indonesia as a license on Milky, Fruity and Mut mut products toward information allotted in the packaging. Besides, it also explored the interest of kids to the character. It was multi method research. It involved desktop-research and survey which enabled respondents to bring out their perception. The results of this study was Iron Man considered to be a very appropriate character, reflected from the survey and comparison toward the nutrition. Thus, from this research, it is a suggestion for Frisian Flag to focus Iron Man character as one of the steps to increase sales and consumer buying interest.
\end{abstract}

Keywords: Licence, Superhero, Interest

\begin{abstract}
ABSTRAK
Penelitian ini merupakan analisis yang bertujuan untuk melihat kesesuaian antara karakter super hero (Iron Man, Spiderman, Thor, Captain America) yang dipilih oleh Frisian Flag Indonesia sebagai lisensi produk Milky, Fruity dan Mut mut terhadap informasi yang diberikan pada kemasan. Selain itu, juga mengeksplorasi minat anak-anak untuk memilih karakter. Itu adalah penelitian multi metode. Ini melibatkan penelitian desktop dan survei yang memungkinkan responden untuk menunjukkan persepsi mereka. Hasil penelitian ini adalah Iron Man yang dianggap karakternya sangat tepat, tercermin dari hasil survei dan perbandingan terhadap nutrisi. Dengan demikian, dari penelitian ini, merupakan saran bagi Frisian Flag untuk memfokuskan karakter Iron Man sebagai salah satu langkah untuk meningkatkan penjualan dan minat beli konsumen.
\end{abstract}

Kata kunci: lisensi, superhero, minat 


\section{PENDAHULUAN}

PT Frisian Flag Indonesia adalah produsen produk-produk nutrisi berbasis susu untuk anak-anak di Indonesia dengan merek Frisian Flag, yang juga dikenal sebagai Susu Bendera. Frisian Flag telah menjadi bagian dari pertumbuhan keluarga Indonesia selama lebih dari 90 tahun. Selama itu pula, Frisian Flag selalu memberikan komitmennya untuk terus berkontribusi membantu anak-anak Indonesia meraih potensinya yang tertinggi, melalui produk-produk bernutrisi tepat. Frisian Flag memiliki lebih dari 30 penghargaan dari berbagai jenis kegiatan di indonesia, antara lain Halal Award 2013, Indonesia Retailer Satisfaction Index 2013, Innovative nutritiouss food 2012, Indonesia Original Brands 2011 dan lain sebagainya.

Frisian Flag Indonesia membuat produk susu siap minum dengan nilai gizi Energi Total 50 kkal yang terdiri dari karbohidrat, natrium, kalium, vitamin $\mathrm{A}$, vitamin $\mathrm{D} 3$, vitamin $\mathrm{B} 1$, vitamin $\mathrm{B} 3$, vitamin $\mathrm{B} 6$, vitamin B12, kalsium, dan fosfor sebagai pendukung pertumbuhan anak. Produk yang diluncurkan Frisian Flag Indonesia dengan nilai gizi tersebut adalah Frisian Flag'Milky', Frisian Flag 'Fruity' dan Frisian Flag 'Mut Mut'. Sebagai strategi pemasaran dalam pendekatan terhadap konsumen usia 7-12 tahun yang berada pada periode operasional kongkret Frisian Flag Indonesia melakukan lisensi produk dengan karakter film yang diketahui oleh anak-anak. Strategi tersebut dilakukan sesuai dengan jurnal Fabio Albanese "We can define licensing as a commercial activity that involves the temporary transfer to a third party of the right to use a name, image, brand or logo which has been officially registered and which is protected by law." Dari berbagai macam karakter didalam film Frisian Flag Indonesia hanya memilih 4 karakter film saja. Beberapa karakter yang dipilih adalah karakter superhero yang memiliki kekuatan tertentu didalam membela kebenaran. Superhero yang dipilih oleh Frisian Flag Indonesia adalah Captain America, Iron Man, Thor dan
Spiderman. Ke empat super hero tersebut melekat pada kemasan susu Frisian Flag'Milky', Frisian Flag 'Fruity' dan Frisian Flag 'Mut Mut'. Masing-masing kharakter tersebut memiliki kekuatan yang berbedabeda.

Kekuatan yang dimiliki superhero tersebut antara lain seperti memiliki perangkat pakaian robot, palu dengan kekuatan dewa, kemampuan mengeluarkan jaring laba-laba dan lainnya. Dengan kekuatan tersebut masih belum dapat diketahui kesesuaian antara kekuatan dari ke empat superhero tersebut dengan kandungan nilai gizi dan vitamin yang dimiliki oleh produk susu Frisian Flag'Milky', Frisian Flag 'Fruity' dan Frisian Flag 'Mut Mut'. Dengan konsumen usia 7-12 tahun di indonesia yang memiliki berbagai macam tokoh superhero sebagai karakter yang paling disukai, juga belum dapat diketahui apakah pemilihan karakter superhero yang dipilih oleh Frisian Flag sudah tepat kepada konsumen anak usia 7-12 tahun di Indonesia, karena seperti yang dipaparkan dalam penelitian Dyzka fadela adalah "seorang yang dijadikan brand endorser harus memiliki personifikasi yang sama dengan personifikasi produk" Untuk itu, peneliti tertarik untuk melihat bagaimana karakter dari ke-4 tokoh superhero yang dipilih oleh Frisian Flag Indonesia yang digunakan sebagai penarik konsumen dalam brand terbarunya,dan karakter yang mana sajakah yang sebenarnya anak-anak pada usia 7-12 tahun paling sukai dari keseluruhan anggota avenger.

\section{PERMASALAHAN}

Proses lisensi tersebut belum dapat dikatahui kesesuaian antara kandungan vitamin yang dimiliki susu tersebut dengan pemilihan karakter super hero, dimana karakter tersebut harus menjadi dasar personifikasi yang sama antara kandungan didalam produk dengan kemampuan atau kekuatan dari karakter yang dilisensi. Perlu dikatahui tentang ketepatan perusahaan dalam 
menentukan karakter-karakter super hero yang telah dilisensi apakah sudah sesuai dengan keinginan konsumen dan sesuai dengan informasi pendukung lainnya. Diantara ke 4 karakter tersebut manakah yang memiliki penilaian paling baik sebagai salah satu rencana untuk menarik konsumen dalam membeli produk susu Frisian Flag'Milky', Frisian Flag 'Fruity' dan Frisian Flag 'Mut Mut'

\section{PEMBAHASAN}

Hasil jurnal yang ditulis oleh Dedy Aguspriandono dengan responden ibu-ibu Berdasarkan hasil analisis disimpulkan faktor yang signifikan berpengaruh dalam keputusan menggunakan susu pertumbuhan sebagai asupan gizi tambahan bagi balitanya adalah komposisi dan nilai gizi, faktor efek dan manfaat pada anak, dan keamanan produk. Dari hasil penelitian tersebut, informasi kandungan didalam minuman yang akan dikonsumsi anak-anak menjadi hal yang paling diperhatikan sebelum mempersilahkan anak mereka mengkonsumsi minuman tersebut. Informasi yang tertera pada kemasan minuman susu dari Frisian Flag adalah vitamin A, B1, B2, B12, D3 dan kalsium. Informasi kandungan vitamin tersebut dibuat dengan tingkat legibility atau tingkat keterbacaannya lebih baik dibandingkan informasi nilai gizi yang berada di samping dari kemasan tersebut. Sehingga konsumen lebih dahulu menangkap informasi kandungan susu berupa vitamin A, B1, B2, B12, D3 dan kalsium.

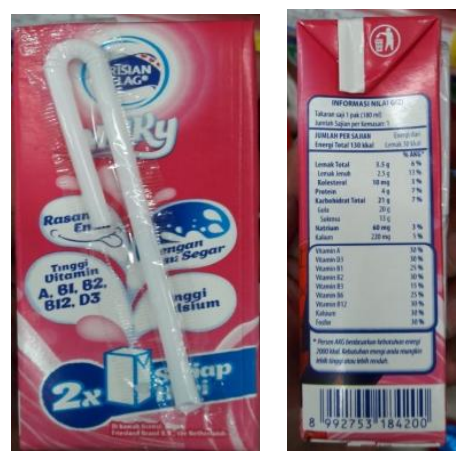

Gambar 1 informasi kemasan
Manfaat yang terkandung didalam Vitamin A bagi anak adalah untuk kesehatan penglihatan, pertumbuhan tulang, serta membantu melindungi tubuh dari infeksi. Vitamin A juga berguna untuk kesehatan dan pertumbuhan sel dan jaringan tubuh, terutama pada jaringan rambut, kuku, dan kulit. Untuk manfaat vitamin B1 adalah untuk membantu memproduksi energi, fungsi jantung yang tepat, produksi sel darah merah. Vitamin B2 mencegah penyakit, memastikan kesehatan mata, membantu memperbaiki jaringan, meningkatkan kekebalan tubuh. Vitamin B12 mengurani resiko dari penyakit kangker, vitamin D3 untuk menjaga kesehatan tubuh secara menyeluruh, memperbaiki osteoporosis, tulang dan gigi, sebagai antioksidan untuk kekebalan tubuh, anti kanker, untuk pengobatan tambahan pada diabetes mellitus, memperbaiki reaksi alergi dan mempertahankan fungsi paru dan jantung.

Dari informasi yang ditampilkan pada kemasan minuman tersebut didapat kesimpulan bahwa manfaat yang dapat diperoleh konsumen disaat mengkonsumsi susu tersebut adalah mampu memproduksi energi yang lebih, menambah kekuatan dari tubuh, memiliki kekebalan tubuh yang lebih baik. Dengan informasi tersebut target pasar yang membeli produk sudah dapat memperoleh informasi yang diharapkan sebagai pembeli, sedangkan sebagai pengguna produk yaitu anak-anak, Frisian Flag memberikan visual yang dapat menarik minat anak-anak dengan cara lisensi dengan karakter super hero. Super hero tersebut adalah Captain america, Ironman, THOR, Spiderman.
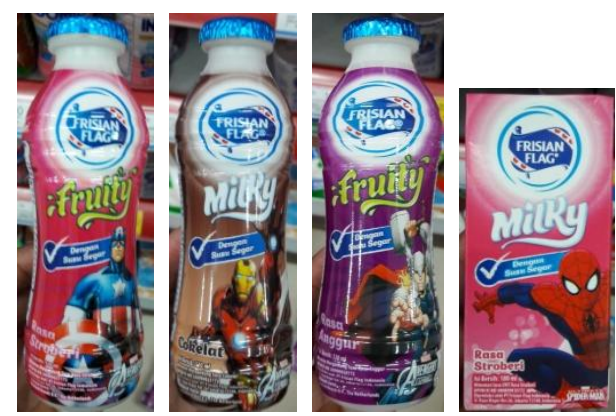
Gambar 2 karakter super hero pada kemasan

Seperti yang dikemukakan oleh Dyzka fadela adalah "seorang yang dijadikan brand endorser harus memiliki personifikasi yang sama dengan personifikasi produk" maka dari hasil kesimpulan informasi tentang kandungan gizi tersebut, akan dibandingkan dengan kharakter yang telah ditentukan perusahaan sebagai lisensi. Sesuai dengan informasi yang terdapat dalam situs resmi pembuat karakter tersebut (marvel.com), terdapat 6 indikator yang dimiliki tiap-tiap super hero yang diciptakannya. Indikator tersebut adalah durability, energy, fighting, intelligence, speed, dan strength. dari ke 6 indikator tersebut dilakukan penyesuaian dengan hasil kesimpulan dari kandungan vitamin yang terdapat didalam susu Frisian Flag, yaitu mampu memproduksi energi yang lebih, menambah kekuatan dari tubuh, memiliki kekebalan tubuh yang lebih baik. Dari hasil penyesuaian tersebut diperoleh indikator yang sesuai yaitu durability, energy dan strength. berikut adalah indikator dari masing-masing karakter super hero yang diperoleh dari situs resmi marvel.com.

\begin{tabular}{|l|l|l|l|l|l|l|l|}
\hline POWERGRID & $\mathbf{1}$ & $\mathbf{2}$ & $\mathbf{3}$ & $\mathbf{4}$ & $\mathbf{5}$ & $\mathbf{6}$ & $\mathbf{7}$ \\
\hline DURABILITY & & & & & & & \\
\hline ENERGY & & & & & & & \\
\hline FIGHTING & & & & & & & \\
\hline INTELLIGENCE & & & & & & \\
\hline SPEED & & & & & & & \\
\hline STRENGTH & & & & & & & \\
\hline
\end{tabular}

Gambar 3 Powergrid Captain america

\begin{tabular}{|l|l|l|l|l|l|l|l|}
\hline POWERGRID & $\mathbf{1}$ & $\mathbf{2}$ & $\mathbf{3}$ & $\mathbf{4}$ & $\mathbf{5}$ & $\mathbf{6}$ & $\mathbf{7}$ \\
\hline DURABILITY & & & & & & & \\
\hline ENERGY & & & & & & & \\
\hline FIGHTING & & & & & & & \\
\hline INTELLIGENCE & & & & & & \\
\hline SPEED & & & & & \\
\hline STRENGTH & & & & & & \\
\hline
\end{tabular}

Gambar 4 Powergrid Ironman

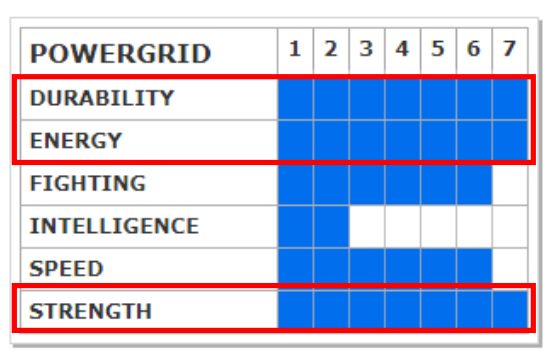

Gambar 5 Powergrid Thor

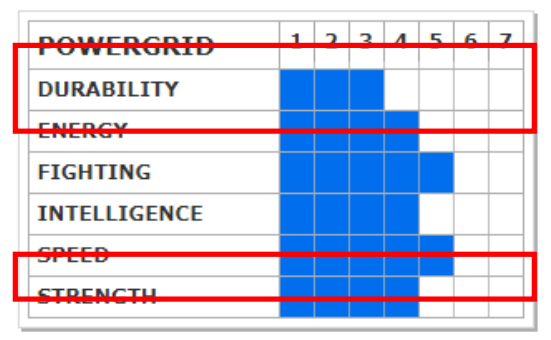

Gambar 6 Powergrid Spiderman

Dilihat dari durability, energy dan strength dari masing-masing karakter yang memiliki nilai terbesar adalah THOR yang mana memiliki nilai maksimum untuk ketiga aspek yang masing masing memiliki nilai 7 . Yang kedua adalah ironman yang memiliki nilai yang lebih rendah 1 poin yaitu 6 dari masing-masing aspeknya. Sedangkan untuk captain america dan spiderman memiliki angka yang cukup rendah yaitu dibawah 4 . Dengan rendahnya angka yang dimiliki dari spiderman dan captain america maka antara informasi yang ditampilkan dengan karakter super hero yang terdapat pada kemasan tersebut tidak sejajar.

Dari ke karakter super hero tersebut dilihat dari urutan karakter super hero yang paling diminati berdasarkan dari situs resmi marvel yang pertama adalah spiderman, Captain Marvel, Iron Man, Luke Cage, Hulk, Thor, Captain, America, Wolverine, Black Widow, Dare Devil. 


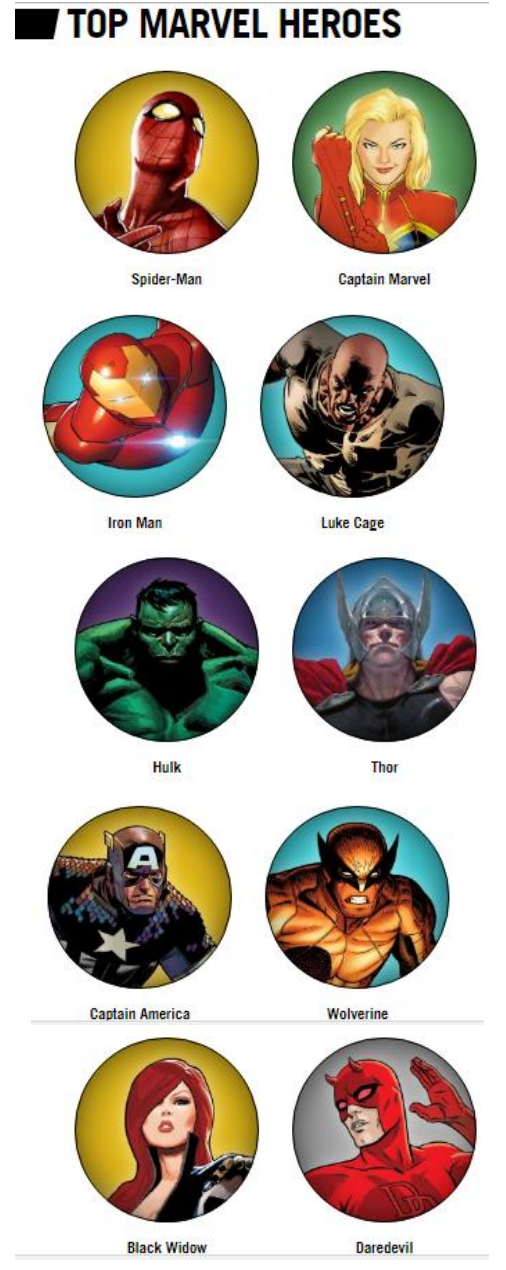

Gambar 7 Top Marvel Heroes

Dari data tersebut keempat karakter yang dipilih sebagai lisensi produk masuk ke dalam karakter terfavorit menurut marvel.com.

Dengan data karakter super hero yang telah disimpulkan oleh situs marvel disesuaikan dengan karakter yang terdapat pada film-film super hero yang telah dirilis dan sukses maka diperoleh hasil pembahasan sebagai berikut.

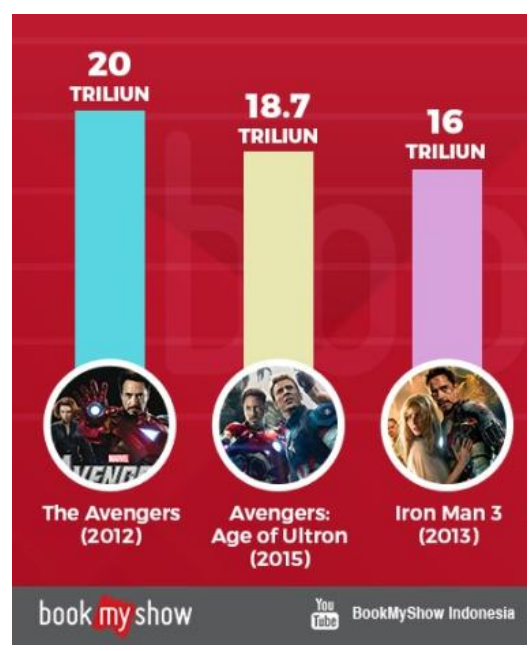

Gambar 8 Film Super hero avenger dengan pendapatan tertinggi

Film avenger tahun 2012 berada di peringkat pertama dengan 20 triliun yang mana didalam film tersebut terdapat karakter Iron Man, Captain America, Hulk, Thor dan Black widow karakter tersebut juga berada di dalam 10 karakter terbaik dari situs resmi. Untuk peringkat ke 2 adalah film Avengers: Age of Ultron pada tahun 2015 dengan pendapatan 18,7 triliun, karakter yang ada didalam film tersebut masih sama dengan film avenger tahun 2012 tetapi ditambah beberapa karakter baru. Tetapi karakter tersebut tidak masuk ke dalam 10 karakter terbaik. Pada peringkat ke 3 adalah film yang hanya fokus kepada 1 karakter saja yaitu Iron Man. Yang mana film berjudul Iron Man 3 tersebut merih keuntungan sebesar 16 Triliun.

Dari ketiga film super hero tersukses tersebut karakter super hero yang telah di lisensi oleh Frisian Flag didapat kesimpulan bahwa Iron Man, Captain America dan Thor masuk ke jajaran 3 besar film yang tersukses, tetapi karakter Spiderman tidak masuk ke dalam 3 film terbaik tersebut.

Dari kesimpulan data-data tersebut kemudian dilakukan penyebaran kuesioner untuk menanyakan kepada konsumen anakanak usia 7-12 tahun tentang karakter yang disukai,dari 138 responden diperoleh data sebagai berikut. 


\section{Hasil polling avenger}

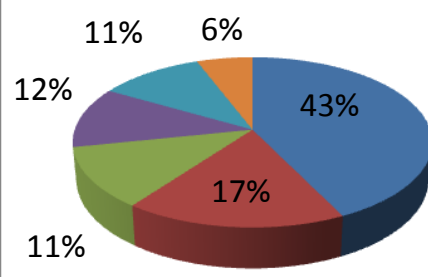

Diagram 1 hasil penyebaran kuesioner

\begin{tabular}{|r|l|r|}
\hline 1 & Hasil polling avenger & Column1 \\
\hline 2 & IRON MAN & 59 \\
\hline 3 & SPIDERMAN & 24 \\
\hline 4 & CAPTAIN AMERICA & 16 \\
\hline 5 & BLACK WIDOW & 16 \\
\hline 6 & THE HULK & 15 \\
\hline 7 & THOR & 8 \\
\hline
\end{tabular}

Tabel 1 hasil penyebaran kuesioner

Dari keempat karakter yang telah ditentukan oleh Frisian Flag, terdapat 3 karakter yang menjadi super hero yang disukai oleh anak-anak, yaitu Iron man dengan 59 suara, yangmana hasil wawancara kepada salah satu responden mengatakan bahwa pakaian pakaian robot yang digunakan dan kecanggihan dari pakaian tersebutlah yang menyebabkan Iron Man menjadi pilihan. Kemudian untuk Spiderman memiliki 24 suara, setelah dilakukan wawancara kepada salah satu responden, juga memiliki jawaban yang tidak berbeda jauh, yangmana spiderman memiliki pakaian yang memiliki teknologi yang canggih sama seperti Iron Man. Hal tersebut dapat dikatakan bahwa informasi yang diperoleh anak-anak tentang karakter Spiderman berasal dari film terbaru di tahun 2017 yang berjudul Spiderman : Homecoming dimana didalam film tersebut, karakter spiderman memperoleh pakaian untuk bertarung yang dibuat oleh Iron Man. Pada peringkat ke 3 terdapat Captain America dengan 16 suara, yang mana alasan dari salah satu responden memilih super hero tersebut karena responden memiliki pakaian lengkap yang sama dengan Captain America. Untuk karakter super hero Thor,memiliki angka yang cukup rendah hanya 8 responden yang memilih karakter tersebut.

\section{KESIMPULAN}

Berdasarkan informasi kandungan dari minuman tersebut Frisian Flag telah memberikan informasi yang memiliki legibility atau tingkat keterbacaannya yang jelas dalam informasi vitamin A, B1, B2, B12, D3 dan kalsium. Berdasarkan informasi kandungan nutrisi yang dimiliki disejajarkan dengan karakter super hero Captain america, Ironman, Thor, dan Spiderman hanya terdapat 2 karakter yang sesuai dengan nilai nutrisi yaitu Thor dan Iron Man. Sedangkan hadil analisis berdasarkan 3 film super hero terlaris menunjukkan 3 dari ke 4 karakter tersebut masuk ke dalam film terlaris tersebut. Yaitu Captain america, Ironman dan Thor. Dari hasil penyebaran kuesioner kepada anak usia 7-12 tahun diperoleh 3 teratas karakter yang paling diminati, yang pertama Iron Man dengan 59 suara, Spiderman dengan 24 suara, dan Captain America dengan 16 suara.

Berdasarkan hasil tersebut saran yang dapat diberikan adalah, karakter Iron Man menjadi karakter yang sangat sesuai dilihat dari analisis kesesuaian karakter dengan manfaat dari susu, film yang memiliki pendapatan tertinggi, dan polling yang diberikan kepada 138 responden karakter Iron Man selalu memiliki poin yang tinggi. Sehingga perusahaan Frisian Flag dapat meningkatkan produksi yang terfokus pada karakter Iron Man sebagai salah satu langkah untuk meningkatkan penjualan dan minat beli konsumen.

\section{UCAPAN TERIMAKASIH}

Penelitian ini dibiayai oleh dana hibah yang diberikan oleh Politeknik APP Jakarta.

\section{DAFTAR PUSTAKA}




\section{Buku}

Arisman. 2004. Gizi dalam Daur Kehidupan:

Buku Ajar Ilmu Gizi. Buku Kedokteran EGC: Jakarta

Belch, G.E \& Belch, M.A. 2004. Advertising and Promotion : An Integrated. Marketing Communication Perspective, New York: Mc.GrawHill.

Kotler, Philip. 2005. Manajamen Pemasaran, Jilid 1 dan 2. Jakarta: PT. Indeks Kelompok Gramedia.

Purwitasari, D., dan Maryanti, D., 2009. Gizi dalam Kesehatan Reproduksi. Nuha Medika. Yogyakarta.

Shimp, T.A. (2010), Advertising, promotion , $\&$ other aspects of Integrated Marketing
Communication, 8th Edition, SouthWestern, Cengage Learning.

\section{Skripsi, disertasi, tesis}

Fabio Albanese, Merchandising and Licensing to Improve Brand Equity. The CocaCola Case (C) SYMPHONYA Emerging Issue in Management, n. 1, 2000-2001 www.unimib.it/symphonya

Dyzka Fadela, analisis brand endorser produk kosmetika mustika ratu studi pada putri indonesia 2010 nadine alexandra dewi ames, Universitas Indonesia

\section{Artikel dari internet:}

www.frisianflag.com diakses pada tanggal 30 agustus 2017

www.marvel.com diakses pada tanggal 5 september 2017

www.detik.com diakses pada tanggal 5 september 2017 